\title{
Acute Toxicity Study And Antioxidant Activities Of Pohpohan Leaves (Pilea trinervia (Roxb.) Wight) and Kenikir (Cosmos caudatus)
}

\author{
Himmi Marsiati ${ }^{1}$, Susi Endrini ${ }^{2}$, Arif Ashari ${ }^{3}$, Fazleen Izzany Abu Bakar ${ }^{4}$, and Mohd Fadzelly \\ Abu Bakar ${ }^{5}$ \\ $\left\{\right.$ himmi.marsiati@yarsi.ac.id $\left.{ }^{1}\right\}$
}

\begin{abstract}
Faculty of Medicine, Universitas YARSI, Jl. Letjend Suprapto Cempaka Putih 10510, Jakarta ${ }^{1,2}$ Herbal Research Centre, Universitas YARSI, Jl. Letjend Suprapto Cempaka Putih 10510, Jakarta ${ }^{1,2,3}$ Faculty of Applied Sciences and Technology, Universiti Tun Hussein Onn Malaysia (UTHM), Hab Pendidikan Tinggi Pagoh, KM1, Jalan Panchor, 84600 Muar, Johor, Malaysia ${ }^{4,5}$

Centre of Research for Sustainable Uses of Natural Resources (CoR-SUNR), Universiti Tun Hussein Onn Malaysia (UTHM), 86400 Parit Raja, Batu Pahat, Johor, Malaysia ${ }^{4,5}$
\end{abstract}

\begin{abstract}
Kenikir (Cosmos caudatus) and Pohpohan (Pilea trinervia) are widely used as a traditional medicine in Southeast Asia including Indonesia and Malaysia for health benefits purposes. Hence, this research aims to evaluate the antioxidant activity and acute toxicity study of herbal teas from Kenikir dan Pohpohan. The antioxidant activity was conducted using 2,2- diphenyl-1-picrylhydrazyl (DPPH) assay. For the acute toxicity study, a total of 36 rats were divided into 6 groups and administered orally with three different doses of plant extracts $(2500,5000$ and $10000 \mathrm{mg} / \mathrm{kg}$ body weight for 14 days. The results showed that Cosmos caudatus had higher antioxidant activity than Pilea trinervia with $\mathrm{IC}_{50}$ value of $64 \mathrm{ppm}$. Meanwhile, for the acute toxicity study, it indicated that both plants extracts teas were not toxic as no mortality was observed after 14 days. Hence, these plants can be developed as pharmaceutical and nutraceutical products for the future.
\end{abstract}

Keywords: Acute Toxicity Study, Antioxidant Activities, Pohpohan, Kenikir.

\section{Introduction}

Cosmos caudatus (Kenikir) is widely used as a traditional medicine in Southeast Asia including Indonesia and Malaysia. The leaves and shoots of this plant can be consumed raw [5].C. caudatus has been reported as a rich source of phytochemical compounds that are linked to many pharmacological activities such as quercetin, catechin, luteolin, stigmasterol and apigenin [11]-[17]. Studies have shown that $C$. caudatus possessed few pharmacological activities as antioxidant, anti-diabetic, anti-hypertensive, anti-inflammatory, anti-microbial and anti-fungal activities [4]-[16]. Moreover, Pilea trinervia or locally known as Pohpohan is a herbaceous plant with a height of more than $5 \mathrm{~m}$. It belongs to the family of Urticaceae. The leaves are soft aromatic and commonly used as an upset for stomachache. The Indonesian people consume the leaves of this plant as a salad [7]. However, until now, the scientific study on this plant is still lacking [13]. Several assays have been frequently used to estimate antioxidant capacities of the plants. One of the assays that is widely used is 2,2-diphenyl-1-picrylhydrazyl 
(DPPH) [8]. In this assay, the free radical scavenging activity of the extract is measured regarding hydrogen donating or radical scavenging ability using the stable free radical DPPH. Furthermore, acute toxicity is defined as the unwanted effect on the target organ that occurs either immediately or at a short time interval after a single or multiple administration of such substance within 24 hours. It is well understood that the toxicity assessment of pharmacological agents is a very important procedure that is usually carried out before they are allowed to enter the market for sale [6]. This includes the development of new drugs, traditional medicines, cosmetics, health supplements, and food. Hence, this study aims to evaluate the antioxidant activity in vitro as well as acute toxicity in vivo of $C$. caudatus and P. trinervia.

\section{Methods}

\subsection{Plant materials and extractions}

The leaves of $C$. caudatus and P. trinervia were extracted with water and the extract was then filtered through a Whatman No. 1 filter paper. The collected filtrates were freeze-dried using a freeze dryer machine (LABCONCO). The samples were further used for measuring DPPH radical scavenging activity and acute toxicity study

\subsection{Determination of 2,2- diphenyl-1-picrylhydrazyl (DPPH) radicals scavenging activity}

The free radical scavenging activity of the extract was measured regarding hydrogen donating or radical scavenging ability using the stable free radical DPPH. $1 \mathrm{mM}$ solution of DPPH in ethanol and also $1 \mathrm{mg} / 1 \mathrm{ml}$ extract solution in ethanol were prepared, and $1.5 \mathrm{ml}$ of this solution was added to $1.5 \mathrm{ml}$ of DPPH. The absorbance was measured at $517 \mathrm{~m}$ against the corresponding blank solution which is prepared by taking $3 \mathrm{ml}$ ethanol. Control was prepared by taking $3 \mathrm{ml}$ of DPPH. The assay was performed in triplicates. Percentage inhibition of free radical DPPH was calculated based on control reading by following Equation 1 [12].

$$
\mathrm{AA} \%=100-\left\{\left[\left(\mathrm{Abs}_{\text {sample }}-\mathrm{Abs}_{\text {blank }}\right) \mathrm{x} 100\right] / \mathrm{Abs}_{\text {control }}\right\}
$$

\subsection{Determination the acute toxicity study}

The purpose of this research was to conduct the acute toxicity study for preparing herbal teas from $C$. caudatus and P. trinervia with BPOMRI (No.7.Tahun 2014) method. A total of 36 rats (female and male) were allocated at random into 6 groups. Three rats were assigned at random to each treatment until 14 days. The rats were administered three different oral doses such as 2500,5000 and $10.000 \mathrm{mg} / \mathrm{kg}$ body weight.

\subsection{Statistical analysis}

Values were presented as mean \pm standard deviation. The $\mathrm{IC}_{50}$ values were calculated using GraphPad Prism 7 software. 


\section{Results}

\subsection{Determination of 2,2- diphenyl-1-picrylhydrazyl (DPPH) radicals scavenging activity}

The results showed that both plants had high antioxidant activity (Table 1).

Table 1. (DPPH) radicals scavenging activity

\begin{tabular}{ll}
\hline Plants & Antioxidant activity \\
\cline { 2 - 2 } & $\mathrm{IC}_{50}(\mathrm{ppm})$ \\
\hline Cosmos caudatus & 64 \\
Pilea trinervia & 173 \\
\hline
\end{tabular}

\subsection{Acute toxicity study}

Acute toxicity testing is usually carried out to determine the effect of a single dose of the compound to the animals. Generally, this test is recommended for two types of animals (rodents and nonrodents). The compound tested is given to the experimental animals with different doses and observed for 14 days. Mortality occurred during the testing period were observed and recorded morphologically, biochemically, pathologically and histopathologically. Acute toxicity testing is very important in determining the value of lethal dose $\left(\mathrm{LD}_{50}\right)$, the amount of an ingested substance that kills 50 percent of a test sample. In general, the determination of lethal dose requires a large number of animals, which is a main constraint to the toxicity testing. In this study, a total of 36 rats were divided into 6 groups. Three rats were assigned at random to each treatment until 14 days. The rats were administered with three different oral doses (2500, 5000 and $10000 \mathrm{mg} / \mathrm{kg}$ ). We carried out an acute toxicity test in order to see whether the plant extracts tested can cause immediate death. In addition, since most people consume both of these plants as raw and fresh vegetables, Thus acute toxicity test must be taken into consideration. Based on the results obtained, all the male and female Wistar rats were found to be healthy at the end of 14 days. This suggested that both individual plants, as well as its combination, did not cause mortality to the animals tested at three different doses $(2500,5000$, and $10,000 \mathrm{mg} / \mathrm{kg}$ body weight).

\section{Discussion}

\subsection{Determination of 2,2- diphenyl-1-picrylhydrazyl (DPPH) radicals scavenging activity}

However, $C$. caudatus exhibited higher antioxidant activity than $P$. trinervia with an $\mathrm{IC}_{50}$ value of $64 \mathrm{ppm}$. This current study was in line with Wong et al. [21] where they found that among aqueous extracts of 25 tropical plants, C. caudatus exhibited the highest DPPH free radicalscavenging activity. Other study also reported that among the 11 vegetables tested, ethanol extracts of $C$. caudatus exhibited the highest anti-oxidant activity when measured by $1,1-$ diphenyl-2-picrylhydrazyl (DPPH) [10]. Hence, this current finding has further indicated that $C$. caudatus is a good source of anti-oxidant. 


\subsection{Acute toxicity study}

This suggested that both individual plants, as well as its combination, did not cause mortality to the animals tested at three different doses $(2500,5000$, and $10,000 \mathrm{mg} / \mathrm{kg}$ body weight). The absence of death in experimental animals causes the LD50 value to be unnecessarily determined [14]. If the maximum dose does not cause the death of experimental animals, then $\mathrm{LD}_{50}$ is expressed with a false $\mathrm{LD}_{50}$ or not the actual $\mathrm{LD}_{50}$ [18]. Therefore, this current study showed that the water extract of $C$. caudatus and P. trinervia as well as at concentrations of 2500, 5000, and $10000 \mathrm{mg} / \mathrm{kg}$ body weight were said to be in the non-toxic category. A study done by Amna et al. [3] showed that the acute oral ethanol extract of $C$. caudatus was found well tolerated by rats up to $5 \mathrm{~g} / \mathrm{kg}$ body weight, and they showed neither mortality nor any sign of toxicity. Hence, this showed that the median lethal dose $\left(\mathrm{LD}_{50}\right)$ of $C$. caudatus extract was greater than $5 \mathrm{~g} / \mathrm{kg}$ body weight.

\section{Conclusion}

In this study, we have demonstrated the antioxidant activity and toxicity of $C$. caudatus and $P$. trinervia. For the antioxidant activity, $C$. caudatus exhibited higher antioxidant activity than $P$. trinervia with an $\mathrm{IC}_{50}$ value of $64 \mathrm{ppm}$. For the acute toxicity study, it can be concluded that both plants were not considered to be toxic and the $\mathrm{LD}_{50}$ value was likely to be more than 10000 $\mathrm{mg} / \mathrm{kg}$ body weight. Therefore, these plants can be developed as pharmaceutical and nutraceutical products for future.

\section{References}

[1] Cheng, S.H., et al. (2005) 'Potential medicinal benefits of Cosmos caudatus (Ulam Raja): A scoping review. Journal of Research in Medical Sciences', The Official Journal of Isfahan University of Medical Sciences, 20(10), p. 1000.

[2] Menendez, C., et al. (2011) 'Lack of synergistic interaction between quercetin and catechin in systemic and pulmonary vascular smooth muscle', British Journal of Nutrition, 105(9), pp. 1287 1293.

[3] Suganthy, N. and Devi, K.P. (2016) 'Protective effect of catechin rich extract of Rhizophora mucronata against $\beta$-amyloid-induced toxicity in PC12 cells', Journal of Applied Biomedicine, 14(2), pp. 137-146.

[4] Jeong, Y.M., Ha, J.H. and Park, S.N. (2016) 'Cytoprotective effects against UVA and physical properties of luteolin-loaded cationic solid lipid nanoparticle', Journal of Industrial and Engineering Chemistry, 35, pp. 54-62.

[5] Sriraman, S., et al. (2015) 'Identification of beta-sitosterol and stigmasterol in Bambusa bambos (L.) Voss leaf extract using HPLC and its estrogenic effect in vitro', Journal of Pharmaceutical and Biomedical Analysis, 115, pp. 55-61.

[6] Ren, B., et al. (2016) 'Apigenin and naringenin regulate glucose and lipid metabolism, and ameliorate vascular dysfunction in type 2 diabetic rats', European Journal of Pharmacology, 773, pp. 13-23.

[7] Andarwulan, N., et al. (2010) 'Flavonoid content and antioxidant activity of vegetables from Indonesia', Food Chemistry, 121(4), pp. 1231-1235. 
[8] Perumal, V., et al. (2014) 'Effect of Cosmos caudatus Kunth leaves on the lipid profile of a hyperlipidemia-induced animal model', Journal of Food Chemistry and Nutrition, 2(1), pp. 4351.

[9] Amalia, L., et al. (2012) 'Antihypertensive potency of wild Cosmos (Cosmos caudatus Kunth, Asteraceae) leaf extract', Journal of Pharmacology and Toxicology, 7(8), pp. 359-68.

[10] Ajaykumar, T.V., et al. (2012) 'Anti-inflammatory activity of Cosmos caudatus', International Journal of Universal Pharmacy and Bio Sciences, 1(2), pp. 40-8.

[11] Rasdi, N.H.M., et al. (2010) 'Antimicrobial studies of Cosmos caudatus kunth.(compositae)', Journal of Medicinal Plants Research, 4(8), pp. 669-673.

[12] Endrini, S. (2011) 'Antioxidant activity and anticarcinogenic properties of rumput mutiara (Hedyotis corymbosa (L.) Lam.) and pohpohan (Pilea trinervia (Roxb.) Wight)', Journal of Medicinal Plants Research, 5(16), pp. 3715-3718.

[13] Mishra, K., et al. (2009) 'Anti-malarial activities of Andrographis paniculata and Hedyotis corymbosa extracts and their combination with curcumin', Malaria Journal, 8(1), p. 26.

[14] Gil, M.I., et al. (2002) 'Antioxidant capacities, phenolic compounds, carotenoids, and vitamin C contents of nectarine, peach, and plum cultivars from

[15] Chinedu, E., Arome, D. and Ameh, F.S. (2013) 'A new method for determining acute toxicity in animal models’, Toxicology International, 20(3), p. 224.

[16] Mensor, L.L., et al. (2001) 'Screening of Brazilian plant extracts for antioxidant activity by the use of DPPH free radical method', Phytotherapy Research, 15(2), pp. 127-130.

[17] Wong, S.P., Leong, L.P. and Koh, J.H.W. (2006) 'Antioxidant activities of aqueous extracts of selected plants', Food Chemistry, 99(4), pp. 775-783.

[18] Leong, L.P. and Shui, G. (2002) 'An investigation of antioxidant capacity of fruits in Singapore markets', Food Chemistry, 76(1), pp. 69-75.

[19] Naini, A. (2008) 'Uji toksisitas akut ekstrak daun Psidium Guava Linn (daun jambu biji) terhadap mencit (Mus Musculus)', Journal of Dentistry Indonesia, 11(2), pp. 63-65.

[20] Rizki, E. (2017) 'Acute toxicity test of sernai leaves (Wedelia biflora) water extract concentrations which orally administered in mice (Mus musculus)', Jurnal Ilmiah Mahasiswa Veteriner 1(3), pp. 540-546.

[21] Amna, O.F., et al. (2013) 'Acute and oral subacute toxicity study of ethanolic extract of Cosmos caudatus leaf in Sprague Dawley rats. International Journal of Bioscience', Biochemistry and Bioinformatics, 3(4), p. 301. 